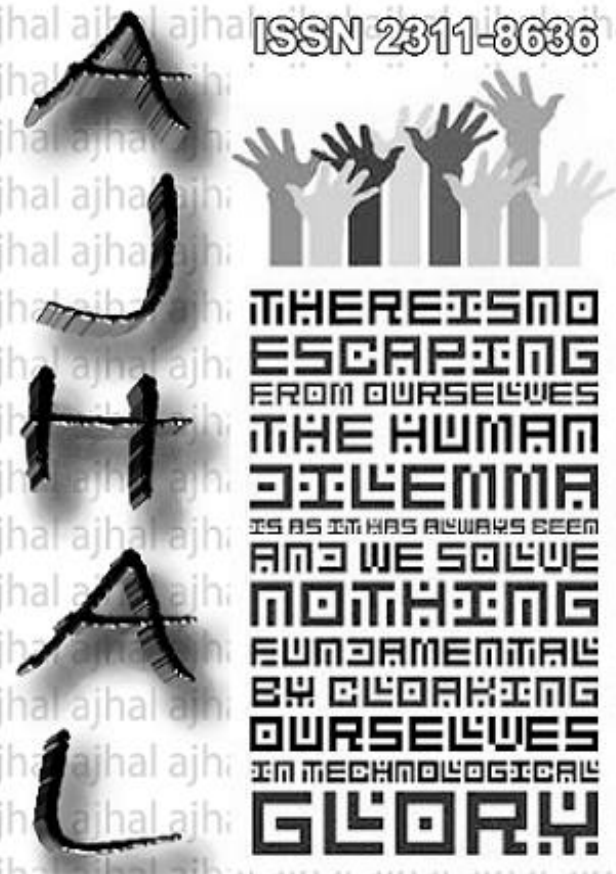

Vol 3, No. 2/2016

Asjan Journal of Humanity, Art and Liteigatul"e 


\title{
Tourism and Crime: The Case of Bangladesh
}

\section{Moniruzzaman Muzib ${ }^{1 *}$, Subrata Banarjee ${ }^{2}$}

\author{
${ }^{1}$ Assistant Professor, Department of Economics, Mawlana Bhashani Science and Technology University, \\ Tangail-1902, BANGLADESH \\ ${ }^{2}$ Assistant Professor, Department of Criminology and Police Science, Mawlana Bhashani Science and \\ Technology University, Tangail-1902, BANGLADESH
}

ISSN: 2311-8636 (Print)

ISSN: 2312-2021 (Online)

DOI prefix: 10.18034/ajhal

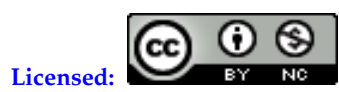

Source of Support: Nil

Conflict of Interest: None Declared

*Email for correspondence:

zamanmuzib@gmail.com

\section{ABSTRACT}

Tourism is an important sector and contributes significantly in the economy of Bangladesh. However, in comparison to others, the tourism industry has not developed and flourished considerably due to some obstacles. The increasing rate of crime is regarded as a potential threat for the industry. Besides some evidence from worldwide suggest that now a day, tourists and visitors are at risk of being victims of violent and property crimes. Some criminological theories such as rational choice theory, routine activity theory and opportunity theory indicate the significant relationship between crime and tourist areas. Mainly the present study attempts to find out the relation between crime and tourism in Bangladesh along with the patterns of crime in tourist areas and the associated risk factors behind it. The qualitative method has been used to conduct the study and data has been collected from secondary sources like various statistics, articles, books, newspapers and so on. The findings of the study revealed that most of the tourist places were affected by criminal activities such as dacoity, robbery, murder, hijacking, riot, women repression, kidnapping, police assault, burglary, theft, etc. Consequently, the frequency and number of tour by the tourist increased at a slower rate and our country are earning lower foreign currency from the tourism sector in recent years. Concerning the high volume of crime, factors like high inequality, mass unemployment, low income, and low level of education has strong influences on crime. Also, it is cheap and easy to buy different types of weapons and bombs in hilly areas due to lack of proper oversight of law enforcing agencies. In 2011, the number of international visitor tourist reached 443,000 generating revenue of BDT6.6 billion. However, in our study period, we found that the number of reported crime has been increasing day by day. Although the police reported crime increased sharply, in most cases residents have been victimized more than the foreigner. For this, the tourism industry is not yet badly affected by police-reported crime in most cases.

Key Words: Tourism, crime, economy, impact

\section{INTRODUCTION AND BACKGROUND OF THE STUDY}

Tourism has become one of the most significant earning sectors in many developing countries. For the last two decades, tourism flourished very fast in the developing countries. Bangladesh has not yet got a better position in this industry after 40 years in comparison to 
her neighbors'. Though Bangladesh got all the potentials to flourish, tourism has been growing at a very slow pace. (Hasan, Ullah and Chowdhury, 2013). Crime is one of the major threats of the tourism industry. Sometimes socio-economic problems of the tourist areas lead to an increase in the crime rates. Evidence from different statistics and research suggests that tourists and visitors are at risk of being victims of violent and property crimes in the cities they visit around the world. It committed against tourists affect tourism by damaging the reputation and image of the spot and also the nation. Glensor and Peak (2004) found that "the most important prerequisite for a successful tourism industry is a reputation for keeping crime under control and guaranteeing tourists' safety.

Some prior research has been conducted to assess the relationship between crime and tourism. Boakye (2011) illustrates that tourists are more vulnerable and are particularly prone to crime. Bernascoand Luykx (2003) illustrate that attractiveness; opportunity and accessibility are key factors influencing crimes against property. Tourists, in particular are vulnerable since they tend to frequent specific locations, are conspicuous and easily noticeable, are unfamiliar with the environment, may not know the local language and customs, and usually carry valuables such as cameras and cash. Steyn et al. (2009) specifically argue that there be the widespread acceptance of the fact that tourists run a higher than average risk of being victimized and that there is an increase in terrorism directed specifically at tourists and resort areas. Baker D, \& Stockton, Susan (2014) in their research Violent crime rates in Honolulu and Las Vegas from 1982 through 1993 showed less of an increase than the increases experienced by other similar cities in the United States for the period studied. The data showed that there was no significant correlation between any of the four serious violent crimes (murder, rape, robbery, aggravated assault) and the number of visitors to Las Vegas. For Honolulu, there was an inverse relationship between the number of visitors and the violent crimes of murder and robbery but a direct and significant relationship to aggravated assault. The results could assist these and other cities in studying more idiosyncratically the relationship between crime and tourism as well as the localization of crimes on visitors to engage in measurement and prevention efforts that would serve visitors as well as residents. S.La. Ferreira and A.C. Harmse in his research on crime and tourism in South Africa showed that Crime against foreign tourists during the period 1996 -1998 had high concentration of crime, and found that tourists are also often victims of crime in towns in less urbanized provinces.

Sheikh Saleh Ahamed in 2010 conducted a research on the impact of tourism in Cox's Bazar, Bangladesh. Among a random sample of residents of different sections of life from the city, 30 questionnaires, with 35 tourism impact statement to know the residents' perceptions. The results show that respondents strongly agree with the idea that tourism provides many economic and socio-cultural benefits, but the residents are ambivalent about its costs. The residents also mentioned some negative consequences on social, cultural, economic and environmental sides. On the social, negative impacts are the increase of crime, social division over the benefit of tourism and, most unwantedly, moral erosion or prostitution. Rahman et. al (2010) have pointed out that, lack of transportation and communication system, lack of wellplanned accommodation, lack of food, lack of entertainment, political instability, lack of coordination among those agencies and other services are the main barriers of tourism in Bangladesh. Ali and Parvin (2010) states that the biggest in the way of tourism in Bangladesh into international location are political instability, low level of managerial skills, social unrest, unwillingness to provide good service, rent seeking, and insecurity. Tuhin and Majumder (2011) have been identified several barriers such as political instability, harassment by the police and the broker in the airport, foreign language, conservative social and religious system, 
image crisis, lack of awareness about the benefits of tourism industry among the general people, illegal hunting and fishing in Sundarban area, absence of trained safe guards, shortage of sufficient accommodation, absence of proper tourism policy, political collision between tribal and Bengali people are the main barriers for tourism development in Bangladesh. Afroz and Hasanuzzaman (2012) identified the fear of abduction, fear of local communities for loss of land, misinterpretation or misconception about tourism in local communities, conflict between minor ethnic community and migrated Bengali for co-existence in hill tracts area, nonsustainable behavior of Bengali and tourist and sometimes by tribal remain the main barrier for the development of tourism industry at Bandarban in Bangladesh.

\section{Theoretical Explanation of TOURISm ANd Crime}

Crime on tourism can be explained by different criminological theory such Ration choice theory, routine activities theory, opportunity theory. The rational choice theory is based on the assumption that before choosing to commit a crime, the criminal considers personal factors or motivation for it, such as their immediate need for benefits, revenge, or excitement, and also situational factors, such as the severity of the consequences and the risk of apprehension. The moment the decision is made to follow through with an unlawful action that will benefit the offender, a crime has been committed. The rational choice approach distinguishes the difference between crime, an event, and criminality, a personality trait, by proposing the idea of offense-specific and offender-specific crimes. Therefore, depending on the given circumstances and opportunities, conventional citizens may also risk criminal behavior, making career criminals not responsible for all crime. People are constructed into criminals for personal reasons, such as prior experience and economic opportunity.

The rational choice view states that offenders commit crimes solely by choice. They rationally plan and choose the type of the crime, the target of the crime, all the way down to the details of the time and place the crime will occur. Criminals may choose the type of crime based on their immediate need for profit. The rational choice view states that offenders commit crimes solely by choice. They rationally plan and choose the type of the crime, the target of the crime, all the way down to the details of the time and place the crime will occur. Criminals may choose the type of crime based on their immediate need for profit. In this regard, tourist may be a potential choice for them because tourists become unaware about the security of a spot. Also in a new place, they cannot sometimes assume the risk factors for occurring crime. Criminals also find it easy to victimize an unknown tourist as they get the opportunity to escape quickly from an unknown tourist. It is also thought that tourist keep a handsome amount of money with them. So they become an easy choice to criminals.

On the other hand, a large body of research illustrates a relationship between routine activities, victim lifestyles, and criminal victimization. In the original study of routine activity theory Cohen and Marcus Felson1979:600 find that daytime burglaries increased over time along with time spent outside of the home during the day. Additionally Miethe, Stafford and long (1987:192) find that person with low daytime and nighttime activity outside of the home have the lowest risk of property victimization, and people who find themselves away from home due to daytime and nighttime activity have the highest risks for crime victimization. Furthermore, Routine activities theory states that there are three elements to facilitate a crime: (1) likely offenders; people who are motivated to commit crimes), (2) suitable targets; , and (3) absence of capable guardians;. In maximum cases, tourist becomes victims of crime as they are chosen as a suitable target for their availability, likely economic gain and unfamiliar to places. Moreover, law enforcement agencies do not always remain present in tourist spots. 
In situational crime prevention (SCP) opportunity is considered a cause of crime. Felson and Clarke (1998) suggest that there are ten ways that theory can assist when thinking about crime prevention. Opportunity theory states that an offender will commit more crime when suitable opportunity will come easily to him. The role of victim is very significant here. If victims create more opportunities to become victimized, offenders will commit more crime. One of the propositions of opportunity theory is that crime opportunities are concentrated in time and space - Dramatic differences are found from one address to another even in a high crime area. Crime shifts greatly by the hour and day of the week, reflecting the opportunities to carry it out. So, specific locations and tourism activities tend to have higher levels of crime. Certain types of tourism activities may influence crime, perceptions of crime and personal safety. Sometimes tourist spots become the hotspots of crime. Crime hotspots not only relate to specific locations and types of crimes, but also to time. In many tourist areas crime in night-time is of particular concern. Besides, during peak tourism seasons criminal activities increase as increased number of tourist creates in more potential victims. Tourists are particularly vulnerable because they are unfamiliar with the environment and how to seek the assistance of law enforcement agencies. The most common form of criminal activity is petty property crime. Most of these criminal acts are opportunity crimes when criminals get easy access to victims (Perry, 2013).

\section{OBJectives OF The Study}

Mainly the study attempts to reveal the relation between crime and tourism in Bangladesh. The other objectives of the study are

- To know the patterns of crime in tourist areas;

- Assess the risk factors of crime in tourist areas;

- To find out the impact of crime in the tourism sector.

\section{Methodology}

The determination of appropriate research design for terrorism and other barriers for tourism is rather difficult in the context of Bangladesh because there have been existed a lot of methodological limitations in the field of contemporary issues. Firstly, the preserving data on tourism and terrorism are inadequate, and it has validity and reliability problems. Secondly, the people who are engaged them in terrorism and other types of dangerous activities such as terrorism do not share their information to the researcher. Thirdly, the people do not show their special interest on knowing about tourism. Fourthly, the previously reliable documents about tourism related documents are insufficient to maintain support for building a policy making. Although such type of problems the main work of this research design is to explain about the terrorism and other barriers for tourism. The research study is embedded within the qualitative framework. It is an explanatory research where the barriers of tourism have been described. The study will help us to find out the problems, designing solution and discovering policy making.

The research is based on the secondary information because of the unavailability of primary data, bears lot of time, high costs, mismanagement, the minimum level of data and high-risk factors involved where collecting terrorism and other types of related data and in the primary level, the data may be misdirected by the researcher. However, in the secondary source, the proper data are available, bears less time, the data ensured validity and reliability, explore the remedial measures of existing problem and the data are guided by the expertise researcher and institution. The terrorism-related data have been selected 
from the renowned newspaper of Bangladesh (from 1997 to 2011) by using an effective checklist while all types of necessary information included. For ensuring accuracy and reliability of results, SPSS software and excel have been used to show the relationship between the variables and their effectiveness.

\section{FINDINGS}

\section{Patterns of crime in tourist area}

Most attractive tourist destinations are situated in Dhaka, Chittagong, Sylhet, and Khulna region. Every year thousands of visitors come to our country in order to enjoy its gorgeous and eye catching beauty. Our country earns huge foreign currency from this sector.

\begin{tabular}{|l|c|c|c|c|c|c|c|c|c|c|c|c|}
\hline Year & Dacoity & Robbery & Murder & $\begin{array}{l}\text { Speedy } \\
\text { Trail }\end{array}$ & Riot & $\begin{array}{c}\text { Woman } \\
\text { \& Child } \\
\text { Repression }\end{array}$ & $\begin{array}{l}\text { Kidna } \\
\text { pping }\end{array}$ & $\begin{array}{l}\text { Police } \\
\text { Assault }\end{array}$ & Burglary & Theft & Others & $\begin{array}{l}\text { Total } \\
\text { Cases }\end{array}$ \\
\hline $\mathbf{2 0 1 0}$ & 474 & 489 & 2550 & 792 & 71 & 10310 & 479 & 202 & 1590 & 3946 & 48171 & 52738 \\
\hline $\mathbf{2 0 1 1}$ & 442 & 456 & 2536 & 765 & 51 & 13018 & 408 & 292 & 1637 & 4244 & 49764 & 73613 \\
\hline $\mathbf{2 0 1 2}$ & 403 & 430 & 2626 & 912 & 53 & 12748 & 469 & 332 & 1575 & 4117 & 55123 & 78788 \\
\hline $\mathbf{2 0 1 3}$ & 419 & 468 & 2847 & 969 & 92 & 11441 & 469 & 659 & 1576 & 3633 & 55033 & 77606 \\
\hline
\end{tabular}

Source: Comparative Crime Statistics: Bangladesh Police from 2010 to 2013.

So it is a vital sector for our economy. However, these regions were affected by various criminal activities such as Dacoity, Robbery, murder, speedy trial, riot, women repression, kidnapping, police assault, Burglary, theft. Over the past few years, the tourism industry (also these tourist places) has been seriously suffering from the lack of proper safety. There are several types of crime occurred in these tourist places specially Dhaka, Chittagong Sylhet and Khulna regions. According to police statistics, these crimes are increased day by day.

Over the last four year (2010 to 2013), we can see the above- mentioned crimes had been taken place in tourist spots. In 2010 the number of police- reported crime was 52738 which was increased day by day and reported in 2013 was 77606. This increasing reported crime is the big threat for our tourism industry. Dacoity, Robbery, murder, riot, kidnapping, and others play a vital negative role in tourist's decision making while he or she makes a tour or not. Consequently, the frequency and number of the tour by tourist increased at a decreased rate and our country get lower foreign currency from tourism.

\section{Risk factors of crime in tourism}

Bangladesh is a densely populated country of the third world. Most of the people in our country live in under the poverty line, and our economy is highly affected by unemployment, inflation, and other recessions. There are several risk factors of crime that play like a catalog in the tourism industry. Firstly, Bangladesh suffers from high inequality, mass unemployment, low income, and low level of education. These factors have strong influences on crime. According to Bangladesh Bureau of Statistics (BBS) 2010 household survey, 31.5 percent of the total population lives below the poverty line including 17.6 percent who are said to be 'extremely poor.' About 40 percent young people do not get a job due to extreme unemployment. Consequently, they involve in different types of crime to lead their life. Secondly, most of the tourist places of the southern part of Bangladesh are situated in the hilly area such as Cox's-bazar, Rangamati, Khagrachori, Bandarban. Hilly area is considered as safer target for doing crime for lack of security, availability of weapon, drugs etc. Moreover, there are lots of refugees migrated from 
Myanmar and India and living in Chittagong and hill tracks area. Besides, in Bangladesh, the rate of crime usually increases in the summer season. Especially the rate of rape increases in hotter months according to Miller (2009). Furthermore; the majority of the people of our country are Muslims. However, in the tourist place, there lived different religious people. Although there are no strong religious debate or conflict in our country but last few years, we saw the fundamentalism and intra- intra religious conflict occurred in the tourist place specially Rangamati-Bandarban district. In 2005, 63 districts out 64 districts were affected by bomb blasting by fundamentalist group that has strong negative effect on tourism according to The Daily Star (18 August' 2005).There is significant social injustice exist in our country. Consequently, the people of our country who did not get the proper judgment, s/he will be revengeful and engage in crime. Our immature media are also responsible for the young people engaging in crime. Also, in most tourist place in our country, we see the insufficient security system exists. It is cheap and easy to buy different types of weapons and bombs in hilly areas due to lack of proper oversight of law enforcing agencies.

\section{IMPACT OF CRIME IN TOURISM SECTOR}

Tourism is one of the most rising sectors due to the presence of great natural beauty, historical monuments and heroic background of the country. Appropriate fostering of enigmatic beauty will certainly appeal to people from all over the world. Consequently, it is considered to be the one of the fundamental pillars of the country's economic development. According to World tourism Organization (WTO), BDT 193.0bn (2.1\% of total GDP) in 2012, and is forecast to rise by $7.7 \%$ in $2013-14$ was the direct contribution of Travel \& Tourism to GDP in Bangladesh.

During the last few years (from 2002 to 2010), a total of 2560957 tourists visited to our country. In 2002, we see 207246 tourists came in our country and in 2010 the number was 303386. From the figure 1, we see the number of tourists increased at fluctuated rate. From the inception of this industry, the sector is trying to attract more tourists to its destinations and to earn more foreign currency.

Figure 1: International Tourists Arrivals in Bangladesh since 2002-2010

\section{Tourist Arrival}

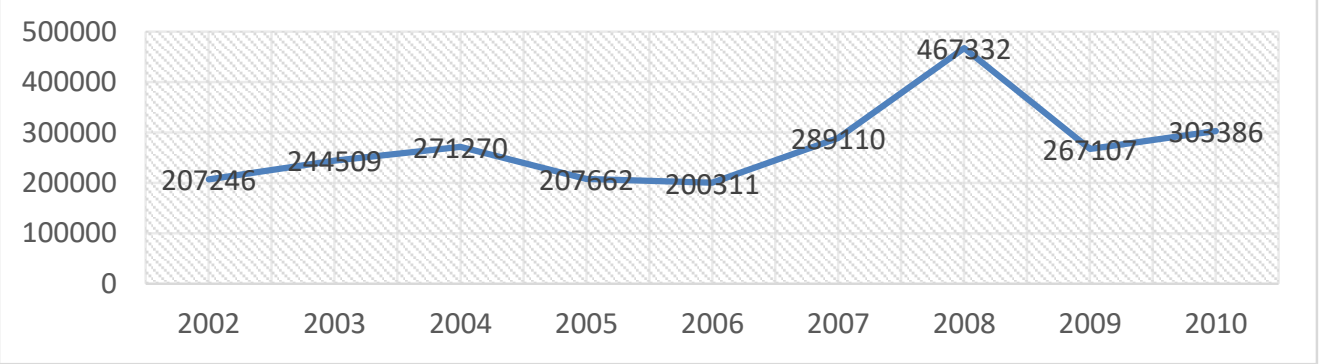

Source: Bangladesh Tourism Board, National Tourism Organization

Figure 2 reveals on an average an increasing trend over the years (2002-2010) in the case of foreign exchange earnings in Bangladesh. From the study period (2002-2003), the trend is stable and from the year (2004 -2006), it was more or less gradually increasing. A decreasing trend is observed in the years 2007. This declining trend could be due to some 
political unrests, especially BDR murder, share market down turn, murder, kidnapping increasing at that time in the country. From the year 2008, this industry booms again with an outstanding trend except the year 2009.

Figure 2: Foreign Exchange Earnings from Tourism \& Other Travels (in million BDT)

\section{Foreign exchange earnings}

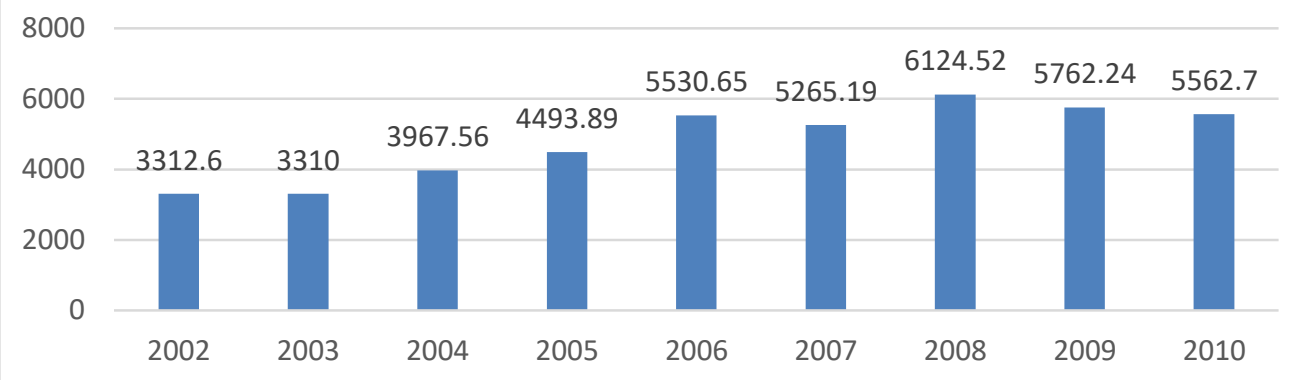

Source: Bangladesh Tourism Board, National Tourism Organization

Bangladesh is a child destination of tourism in the world map. There is a enormous impact of the tourism on the society and economy of the country. Although the growth of the sector is slow, it is improving day by day. Bangladesh tourism industry contributes to healthy GDP and employment opportunities. According to the World Travel and Tourism report of 2011, $1.9 \%$ of total employment is generated by Tourism industry. In 2011, the number of international visitor tourist reached 443,000 generating a revenue of BDT6.6 billion.

Although there is a stable trend of police-reported crime, but fluctuated trend of total tourist arrival is seen in figure 3, but, there is a relation between two events. If we closely look on 2002, we see the total number of tourist is 207246 and the police reported crime was 110222 and in 2003, the total number of tourist arrival is 244509 and the police reported crime was 108854 . From this observation, we can say that police reported crime has a negative impact on the number of tourist arrival.

Figure 3: No. of Tourist vs. No. of police-reported crime

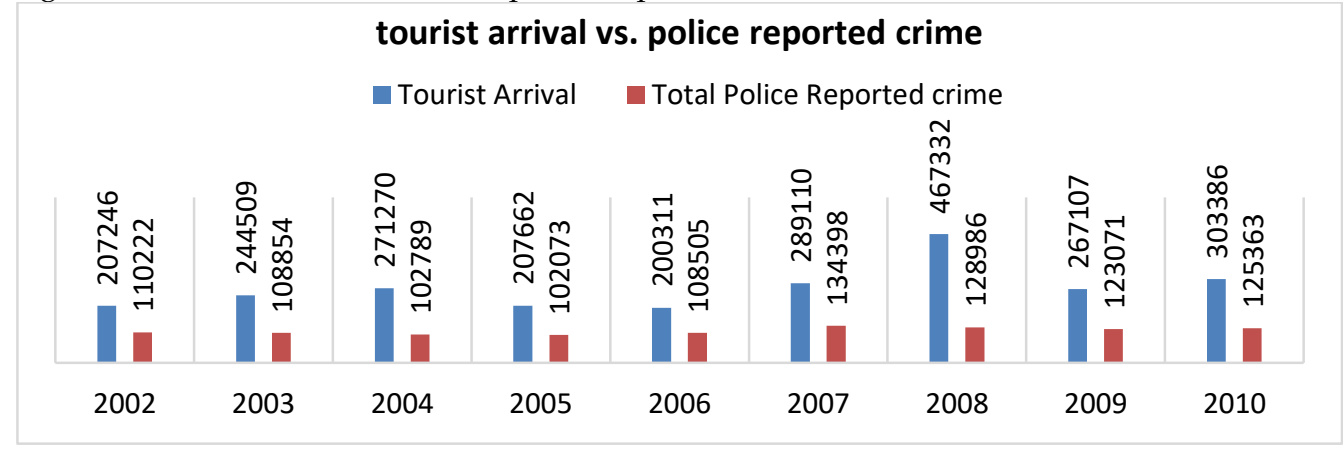

Source: Bangladesh Tourism Board, National Tourism Organization and Comparative Crime Statistics: 2002 - 2010, Bangladesh Police 
During our study period, we cannot always get the same consequence. Overall, Bangladesh is a safe country, with a low but increasing crime rate. Serious crimes against foreigners are rare. Nevertheless, crime does occur both in Bangladeshi tourist place and in the countryside. Crime directed at foreigners is becoming more frequent in major tourist sites, which attract thieves and pickpockets. Minor thefts and Dacoity on overnight trains and buses tend also to occur. The most remote areas of Bangladesh are poorly policed, and there is the risk of attack from armed bandits.

In our study period, from the figure 3, we can see both the total number of police-reported crime and the tourist arrival increased. The number of educated and conscious people is increased day by day. They are fully concerned about their right, social and legal justices. As a result, the number police reported crime increased. Although the police reported crime increased sharply but in most cases victimized are residents not the foreigner. For this, the tourism industry is not badly affected by police-reported crime in most extents.

There is no evidence of global terrorism in Bangladesh, although a small number of bombrelated actions and incidents of unrest do occur. Over the past few years, the country has gone through by some terrorist attacks. First bomb attack was occurred in 2001 at a Bengali New Year concert in Dhaka and at the same year Bomb kills 10 at Sunday mass at a Roman Catholic Church in Baniarchar town. In2005 17 August - Around 350 small bombs go off in towns and cities nationwide. Two people are killed and more than 100 are injured. A banned Islamic group claims responsibility. The mentioned incidents may create threat and fear for the tourists.

\section{CONCLUSION}

In this paper, we have presented information about crime with respect to different years and also tried to show the rate of tourists in different years in comparison to crime. While no single statistic by itself provides a full understanding of the factors contributing to tourists being criminally victimized, the study has attempted to show a relationship of the effect of crime on tourism. Despite the lack of proper statistics, the study will lay out a foundation for future researchers to study on the concerning issues. Law enforcement agencies should take appropriate measures to increase their oversight in tourist spots and thus making the tourist places safer and attracting to tourists.

\section{REFERENCE}

Afroz, Nusrat Nahida and Hasanuzzaman Md. (2012). Problems and Prospects of Tourism in Bangladesh Bandarban District Case, Global Journal of Management and Business Research, Volume 12 Issue 23 Version 1 year, 2012.

Ahmed, Shakil and Akther, Mrs. Suma. (2013). The Threat of Tourism Industry in Bangladesh-A Hotel Industry Prospective, Bangladesh Research Publications Journal, Volume: 8; Issue: 4, page: 204-210.

Akama, J. S. (2000). The efficacy of tourism as a tool for- economic development in Kenya. In A. Bujra (Eds.) economic development in Kenya. In A. Bujra (Eds.) Development policy management in Sub-Saharan Africa: Tourism and African development-Trends andcritical issues. DPMN Bulletin, 7(1). Addis Ababa: Commercial Printing Enterprise. 1972. Tourism sector working paper. Washington: World Bank.

Akteruzzaman., Ishtiaque. (2001). Potenga Seashore, A Rising Horizon for Tourism and Prospects. TheChittagong University Journal of Commerce , 16, 109-111.

Ali, Muhammad Mahboob., Parvin Rehana. (2010). Strategic Management of Tourism Sector in Bangladesh to raise Gross Domestic Product: An Analysis; Business and Economics Working Paper Series, AIUB. 
Aly, Hassan Y \&Strazicich, Mark C. (2000). Terrorism and Tourism: Is the Impact Permanent or Transitory? Time Series Evidence from Some MENA Countries, Ohio State University, Department of Economics.

Auroubindo, Ganesh1., Madhavi, Dr. (2007). "Impact of Tourism On Indian Economy - A Snapshot" Journal of Contemporary Research in Management, Volume-1, No.1, 2 Jan - June 2007

Aziz, H. (1995). Understanding Terrorist Attacks on Tourists in Egypt, Tourism Management, 16: 91-95.

Blanke, Jennifer; Chiesa, Thea; Crotti, Roberto. (2013). The Travel and Tourism Competitiveness Index 2013: Contributing to National Growth and Employment, World Economic Forum.

Edmonds Christopher \&Mak James. (2006). Terrorism and Tourism in the Asia Pacific Region: Is travel and Tourism in a New World After 9/11? East-West Center Working Paper, East West Center.

F.Hasan, the Daily Star: internet Edition, Available: http://www. Thedailystar.net/story.php?nid=5553, 2009.

Ghosh, B. (2001). Tourism and Travel Management, New Delhi: Vikas Publishing House Pvt. Ltd.

Gray, Lori Pennington; Schroeder, Ashley; Kaplanidou, Kiki. (2004). Examining the Influence of Past Travel Experience, General Web Searching Behaviors and Risk Perceptions on Future Travel Intentions, University of Florida.

Henderson, et al. (2010). Tourism and Terrorism: A Hotel Industry Perspective, Journal of Tourism, Hospitality and Culinary Arts.

Kozak, M., Rimmington, R. (1999). Measuring tourist destination competitiveness: conceptual considerations and empirical findings," Hospitality Management, 18, 273-83

Kweka, J. (2004). 'Tourism and the Economy of Tanzania: A CGE Analysis', Retrieved March 31, 2012, http://www.csae.ox.ac.uk/conferences/2004-GPRAHDIA/papers/1f-Kweka-CSAE2004.pdf

Lennon, R; O'Leary, B. (2004). The effect of international terror attacks on German consumers perceptions and future travel plans, Barry University.

Lepp, Andrew \& Gibson, Heather. (2003). Tourist Roles, Perceived Risks and International Tourism, Annuals of Tourism Research, Vol, 30 No 3, pp 606-624.

Lowry, LL.(1994). What is Travel and Tourism and Is There a Difference between Them; AContinuing Discussion, New England Journal of Travel and Tourism, England (28-29)

Majbritt, T. (2010). Eco-Resort for Sustainable Tourism, The Daily Star, April 29.

Miller, J. (2009).21st Century Criminology: A Reference Handbook, Sage. P. 57

Mishra, Sitikantha and Panda, Tapan K. (2001). Socio-Political barrier to Tourism Marketing in South Asia, Indian Institute of Travel and Tourism Management.

Morgan. (2002). A conceptual model of tourism destination competitiveness and attractiveness: Adelaid :Monash University.

Mustapha, NorAzah; Azman, Inoormaziah and Ibrahim, Yahaya. (2013). Barriers to Community Participation in Tourism Development in Island Destination, Journal of Tourism, Hospitality and Culinary, Vol 5, Issue 1.

Rahman, Md., Hossain, S. M., Miti, Kalam, Dr. (2010). “Journal of Bangladesh Institute of Planners, Vol. 3, December 2010"Journal of Bangladesh Institute of Planners, Vol. 3,

Regev, Sharon Teitler; ShahrabaniShosh and Goziker Oksana (2013). The Effect of Economic Crises, Epidemics and Terrorism on Tourism, The Max Stern EmekYezreel College, Israel.

Ritchie, B. J. R., Geoffery C. I.(1993). Competitiveness in international tourism: A Framework for understanding and analysis, in Proceedings of the 43rd Congress of the AIEST. San Carlos de Bariloche, Argentina.

Roy, Mallika\&Borsha, Faria Hossain (2013). Hartal: A Violent Challenges To The Socio-Economic Development of Bangladesh. International Journal of Scientific and Technology Research.

Sonmez, S \&Graefe, A R. (1998). Influence of Terrorism Risk on Foreign Tourism Decisions: Annuals of Tourism Research, 25(1): 112-114.

Sonmez, S. (1998). Tourism, Terrorism and Political Instability, Annuals of Tourism research, 25(2): 416.

Sugiyarto, G., A., Blake, and, M.T. Sinclair. (2003). 'Tourism and Globalization: Economic Impact inIndonesia', Annals of Tourism Research, 30(3): 683-701.

The Daily Star Web version (18 August 2005), Vol 5 No 437.

Timothy, D. (1998). Cooperative tourism planning in a developing destination, Journal of SustaiableTourism , 6 (1), 52-68. 
Tosun, C., \& Timothy, D. J. (2001). Shortcomings in planning approaches to tourism development indeveloping countries: the case of Turkey, International Journal of Contemporary HospitalityManagement, 352.

Tuhin, Md. KashedulWahab and Majumder, Md. Tofael Hossain. (2011). An Appraisal of Tourism Industry Development in Bangladesh, European Journal of Business and Management, Vol 3, No. 3.

Upadhayaya, P.K; Muller, Boker U; Sharma, S.R. (2011). Tourism amidst Armed Conflict: Consequences Copings and Creativity for Peace-building through Tourism in Nepal. The Journal of Tourism and Peace Research, 1(2); 22-40.

Upadhayaya, Pranil Kumar. (2013). Political Instability, Tourism and Peaceful Destination Image: Impacts of Media on the Tripartite Nexus in Nepal, The Journal of Tourism and Peace Research, 3(1) pp 1-19.

$$
--0-
$$

